\title{
Sakubitril/valsartan'ın ölüm şekline (KV ölüm, ani ölüm, KY'ye bağlı ölüm ve tüm nedenli ölüm) etkisi nasıldır?
}

\author{
Dr. İzzet Erdinler
}

Ataşehir Memorial Hastanesi, Kardiyoloji Kliniği, İstanbul

Kalp yetersizliği (KY) tedavisinde gelişmeler olmasına rağmen, hastalığın ilerleme ve ölüm riskinin devam etmesi tedavide yeni yaklaşımların aranmasını gerekli kılmıştır. ${ }^{[1]}$ Dekompanse KY, erişkinlerde en sık hastaneye yatış nedenidir. ${ }^{[2,3]}$ Düşük EF'li KY hastalarında (DEF-KY), ölümlerin yaklaşık \%40'ının esas olarak ventriküler aritminin neden olduğu Ani Kardiyak Ölümle (AKÖ) ile ilişkili olduğu tahmin edilmektedir. ${ }^{[3]}$ Birçok çalışma, DEF-KY'de AKÖ riskinin optimal tıbbi tedavi ile daha düşük olduğunu göstermiştir. Anjiyotensin dönüştürücü enzim inhibitörleri (ACEI), anjiyotensin reseptör blokerleri (ARB), $\beta$-blokerler ve mineralokortikoid reseptör antagonistleri (MRA) ani ölüm ve ilerleyici KY'ye bağlı ölümleri azaltmaktadırlar. İmplante edilebilir kardiyoverter defibrilatör (ICD) implantasyonu ve kardiyak resenkronizasyon tedavisi (CRT) gibi kardiyak cihaz terapileri, seçilmiş hastalarda morbidite ve mortaliteyi daha da azaltmak için önerilmektedir. ${ }^{[3]}$

Kalp yetersizliği için yapılan ilaç ve cihaz tedavileri sağlık sistemi ve hastalar için önemli bir mali yük oluşturmaktadır. İlaç tedavisinde gelişmeler hastalığın kötü prognozunu düzeltebilir ve maliyeti azaltabilir.

Son yillarda DEF-KY tedavisinde önemli bir yenilik, anjiyotensin-reseptör-neprilisin inhibitörü (ARNI) olan sakubitril/valsartan kombinasyonunu içeren yeni bir tıbbi ürünün onaylanması olmuştur. PARADIGM HF çalışmasında kronik DEF-KY olan hastalar sakubitril/valsartan kombinasyonuna karşın enalapril'e randomize edilmiştir. Çalışma sonucunda sakubitril/ valsartan'1n, kardiyovasküler ölüm veya KY nedenli hastaneye yatış birleşik primer sonlanımı, tek başına kardiyovasküler ölüm ve tek başına tüm nedenli mortaliteyi azalttığ 1 gösterilmiştir. ${ }^{[4]}$

PARADIGM HF çalışmasında toplam 1546 hasta ölmüştür. Sakubitril/valsartan alan hastaların 711'i (toplam hastaların \%17'si), enalapril alan hastaların 835'i (toplam hastaların \%19.8'i) çalışma sırasında ölmüştür. Çalışma sonunda yaşıyan hastalar ile ölen hastaların özellikleri karşılaştırıldığında ölen hastalar daha yaşlıdır. Ölüm oranı; erkeklerde, vücut kitle indeksi daha az olanlarda, daha yüksek kalp hızı olanlarda, kreatinin düzeyi fazla olanlarda, özellikle NYHA 2-3 olanlarda ve ek hastalıkları daha çok olanlarda daha yüksektir. KY'den ölüm, ani ölüme göre daha fazla ve natriüretik peptid seviyesi yüksek olanlarda, daha düşük EF olanlarda ve atrial fibrilasyonu olanlarda fazladır.

PARADIGM HF çalışmasında, kardiyovasküler nedenli ölen 1251 hasta (tüm ölümlerin \%80.9) vardır. Kardiyovasküler nedenli ölümler, sakubitril/ valsartan grubunda 558 hastada (hastaların \%13.3), enalapril grubunda 693 hastada (hastaların \%16.5) görülmüştür. Kardiyovasküler nedenli ölümler, çalışma grupları arasında anlamlı farklı iken, kardiyovasküler kaynaklı olmayan ölümler farklı değildir. Ölüm nedeni açık olmayan 66 hasta, çalışma guruplarında benzer şekilde dağılmıştır. ${ }^{[5]}$

Kardiyovasküler ölümlerin \%44.8 AKÖ, \%26.5'i KY kötüleşmesine bağlıdır. Tablo 1'de PARADIGMHF çalışmasında rastlanılan ölüm nedenleri ayrıntılı olarak gösterilmiştir. Her iki ölüm şeklini de sakubitril/valsartan enalapril'e göre anlamlı olarak daha fazla azaltmıştır (ani ölüm için: HR 0.80; sakubitril/valsartan'a karşın enalapril, \%95 CI 0.68-0.94, p=0.008; KY kötüleşmesine bağlı ölüm: HR 0.79, sakubitril/valsartan'a karşın enalapril, \%95 CI 0.64$0.98, \mathrm{p}=0.034)$.

Ani ölüm sonrası başarılı resüsitasyonla yaşayan sakubitril/valsartan grubunda 16 hasta, enalapril grubunda 28 hasta vardır ( $\mathrm{p}=0.07$ ). Resüsitasyon yapılan ve yapılmayan tüm AKÖ olayları kombine edildiği zaman, sakubitril/valsartan kullanan hastalarda enalaprile göre AKÖ'de \%22 relatif risk azalması vardır 
Tablo 1. PARADIGM-HF çalışmasındaki sacubitril-valsartan ve enalapril tedavi grupları arasındaki ölüm oranlar

\begin{tabular}{|c|c|c|c|c|c|c|c|}
\hline & \multicolumn{3}{|c|}{ Sakubitril-Valsartan } & \multicolumn{3}{|c|}{ Enalapril } & \multirow{2}{*}{$\begin{array}{l}\text { HR (\%95 Cl) P-değeri } \\
\text { Sakubitril valsartan- } \\
\text { enapril karşılaştırması }\end{array}$} \\
\hline & Sayı & $\begin{array}{l}\text { Hasta } \\
\text { yüzdesi }\end{array}$ & $\begin{array}{c}\text { Ölüm } \\
\text { yüzdesi }\end{array}$ & Sayı & $\begin{array}{l}\text { Hasta } \\
\text { yüzdesi }\end{array}$ & $\begin{array}{c}\text { Ölüm } \\
\text { yüzdesi }\end{array}$ & \\
\hline Toplam ölüm & 711 & 17 & 100 & 835 & 19.8 & 100 & $\begin{array}{c}0.84(0.76,0.93) \\
P=0.001\end{array}$ \\
\hline Kardiyovasküler ölüm & 558 & 13.3 & 78.5 & 693 & 16.5 & 83 & $\begin{array}{c}0.80(0.72,0.89) \\
P<0.01\end{array}$ \\
\hline Ani ölüm & 250 & 6 & 35.2 & 311 & 7.4 & 37.2 & $\begin{array}{c}0.8(0.68,0.94) \\
P=0.008\end{array}$ \\
\hline Son temas $<1 \mathrm{~s}$ & 167 & 4 & 23.5 & 213 & 5.1 & 25.5 & $\begin{array}{c}0.78(0.64-0.95) \\
P=0.015\end{array}$ \\
\hline $1-24$ saat & 83 & 2 & 11.7 & 98 & 2.3 & 11.7 & $\begin{array}{c}0.84(0.63-1.13) \\
P=0.26\end{array}$ \\
\hline Kalp yetersizliğinin kötüleşmesi & 147 & 3.5 & 20.7 & 184 & 4.4 & 22 & $\begin{array}{c}0.79(0.64,0.98) \\
P=0.034\end{array}$ \\
\hline Dğer nedenler & 161 & 3.8 & 22.6 & 198 & 4.7 & 23.7 & $\begin{array}{c}0.81(0.66-1) \\
P=0.045\end{array}$ \\
\hline Fatal MI & 24 & 0.6 & 3.4 & 33 & 0.8 & 4 & $\begin{array}{c}0.73(0.43,1.23) \\
P=0.24\end{array}$ \\
\hline Fatal İnme & 30 & 0.7 & 4.2 & 34 & 0.8 & 4.1 & $\begin{array}{c}0.88(0.54,1.44) \\
P=0.62\end{array}$ \\
\hline Tahmini ani ölüm & 26 & 0.6 & 3.7 & 23 & 0.5 & 2.8 & $\begin{array}{c}1.12(0.64,1.96) \\
P=0.69\end{array}$ \\
\hline Tahmini kardiyovasküler ölüm & 67 & 1.6 & 9.4 & 95 & 2.3 & 11.4 & $\begin{array}{c}0.70(0.51,0.95) \\
P=0.024\end{array}$ \\
\hline Kardiyovasküler olmayan ölüm & 120 & 2.9 & 16.9 & 109 & 2.6 & 13.1 & $\begin{array}{c}1.09(0.84,1.41) \\
P=0.53\end{array}$ \\
\hline Enfeksiyon & 36 & 0.9 & 5.1 & 34 & 0.8 & 4.1 & $\begin{array}{c}1.04(0.65,1.67) \\
P=0.85\end{array}$ \\
\hline Malinite & 41 & 1 & 5.8 & 41 & 1 & 4.9 & $\begin{array}{c}0.99(0.64,1.52) \\
P=0.96\end{array}$ \\
\hline Pulmoner & 7 & 0.2 & 1 & 13 & 0.3 & 1.6 & $\begin{array}{c}0.53(0.21,1.33) \\
P=0.18\end{array}$ \\
\hline GI & 16 & 0.4 & 2.3 & 9 & 0.2 & 1.1 & $\begin{array}{c}1.77(0.78,4.01) \\
P=0.17\end{array}$ \\
\hline Kaza ile & 13 & 0.3 & 1.8 & 6 & 0.1 & 0.7 & $\begin{array}{c}2.12(0.81,5.59) \\
P=0.13\end{array}$ \\
\hline Diğer & 7 & 0.2 & 1 & 6 & 0.1 & 0.7 & $\begin{array}{c}1.15(0.39,3.43) \\
P=0.80\end{array}$ \\
\hline Bilinmeyen ölüm & 33 & 0.8 & 4.6 & 33 & 0.8 & 3.9 & $\begin{array}{c}0.99(0.61,1.61) \\
P=0.97\end{array}$ \\
\hline
\end{tabular}


(HR 0.78, \%95 CI 0.66, 0.92, p=0.002). AKÖ riskinde azalma hafif-orta dereceli semptomları olan KY hastalarında (NYHA II-III) daha belirgindir. Sakubitril/valsartan ile mortalitedeki azalma pompa yetmezliğine bağlı ölümler için de benzerdir (\%21 relatif risk azalması). PARADIGM-HF çalışmasındaki hastaların büyük çoğunluğunun, genel mortalite ve ani ölümü azalttığı gösterilen ilaçlarla optimal kılavuz tabanlı tıbbi tedavi aldığını dikkate alırsak, bu sonuçlar daha da etkileyicidir. Hastaların \%93'ü $\beta$-bloker ve $\% 55$ 'i bir MRA kullaniyordu.

Ani ölüm üzerindeki tedavi etkisinin büyüklüğü, ICD'si olan (561 ani ölümden 36's1) ve ICD'si olmayanlar (561 ani ölümün 525'i) arasında farklı değildir. PARADIGM HF çalışmasında, $\% 15$ hastada ICD, $\% 7$ hastada CRT vardi.

PARADIGM HF çalışmasında, fatal MI (tüm ölümlerin \%3.7'si), fatal stroke (tüm ölümlerin \%4.1'i), malignite ve infeksiyon (kardiovasküler nedenli olmayan ölümlerin yaklaşık yarısı) tedavi kolları arasında farklı değildir.

Sakubitril/valsartanın, geniş ölçüde kanıtlanmış etkinliğe sahip tedavilere ek olarak mortalite ve ani ölümü daha da azaltma mekanizmaları tam olarak anlaşılamamıştır. ARNİ, neprilisin inhibisyonunun etkisini anjiyotensin-II reseptörünün blokajı ile birleştiren çok sayıda biyolojik yolu içeren karmaşık bir moleküler etki mekanizmasına sahiptir. Neprilisin, birkaç farklı substrat ile her yerde bulunan bir metallopeptidazdır. Kardiyovasküler sistemde neprilisin; vazoaktif peptidler, natriüretik peptidler, adrenomedullin, anjiyotensin-II ve bradikinin gibi birçok vazodilatör ve vazokonstriktör etkileri olan peptitleri yıkar. Neprilisin inhibisyonunun sonucu olarak, renin-anjiyotensin sisteminin ve sempatik sinir sistemi aktivasyonunun zararlı etkilerine karşı koyan ve çeşitli kardiyoprotektif etkileri olan natriüretik peptitlerin dolaşımdaki seviyeleri artar. Natriüretik peptidler, NPR-A (Natriüretik Peptid Reseptörü) ve NPR-B aracıllğı ile hücre içi cGMP'yi ve efektör molekül protein kinaz G'yi arttırır. Bu birkaç sinyal kaskatını devreye sokarak vazodilatasyon ve natriüreze neden olur. Renin-anjiyotensin sistemi ve sempatik sistem inhibe edilir. Daha da önemlisi kardiyak inflamasyon, hücre ölümü, hipertrofi ve fibrozisi azaltır. Sol ventrikül yeniden şekillenmesini azaltma ya da tersine çevirme potansiyeli vardir.

Sakubitril/valsartanın ani ölümün ana nedeni olan ventriküler aritmik olayları azaltarak doğrudan antiaritmik etkileri olması ihtimali düşüktür. Doğrudan elektrofizyolojik temelli aritmi oluşumunu azaltma potansiyeli olmasa da, miyokardiyal fibroz ve duvar gerginliğini azaltarak ventriküler aritmilerin insidansını azaltma potansiyeline sahiptir. Miyokardiyal fibroz, kardiyomiyopatili hastalarda ventriküler aritmilerin temel mekanizması olan reentry'i kolaylaştıran elektriksel homojenliğin bozulmasına ve yavaş iletim alanları üretilmesine neden olur. Miyokardiyal gerilme, uygun bir substrat varlığında ölümcül aritmileri tetikleyebilen daha yüksek prematür atım insidansıyla ilişkilidir. Patolojik yeniden şekillenmenin tersine çevrilmesi ile sol ventrikül fonksiyonunun iyileşmesi de ani ölümün azalmasını bir dereceye kadar açıklayabilir. Sakubitril/valsartanın ejeksiyon fraksiyonu ve sol ventrikül sistolik ve diyastolik hacim indekslerini düzelttiği yakın zamanda yapılan çalışmalarda gösterilmiştir. Sakubitril/valsartanın ek antiaritmik faydası, neprilisinin karışık etkilerinden gelebilir. Aynı zamanda neprilisin substratları olan artmış enkefalinler, endorfinler ve bradikinin seviyeleri, ARNI'nin kardiyoprotektif ve olası anti-aritmik etki mekanizmalarında rol oynayabilir. ${ }^{[6]}$

Natriüretik peptidler, AKÖ’nün umut verici öngördürücüleri arasında yer alan biyobelirteçlerdir. NTproBNP seviyesinde yükselme, prematüre ventriküler aritmi ve ventriküler aritmi nedeni ile ICD şoklarındaki artış ile paraleldir. Sakubitril/valsartan, enalapril tedavisine göre NTproBNP ve troponin seviyesinde azalma sağlar. ${ }^{[7]}$

DEF-KY'li 40.000'den fazla hastayı kapsayan 12 klinik çalışmanın meta analizinde Shen ve ark. ${ }^{[8]}$ AKÖ riskinin, farmakoterapideki ilerlemeden dolay1 son 20 yılda neredeyse yarı yarıya azaldığını göstermiştir. RALES çalışmasında (bu konudaki ilk çalışmalardan) 90 günlük takipte toplam mortalite oranı $\% 2.4$ iken, PARADIGM -HF çalışmasında (en son çalışmalardan) \%1 olmuştur.

Kalp yetersizliği ile ilgili 2016 ESC kılavuzunda, özellikle AKÖ riskini azaltmak için DEF-KY ve ventriküler aritmileri olan hastalarda ACEI, $\beta$-bloker, MRA ve sakubitril/valsartan tedavisi önerilmiştir (Öneri sınıfı I, kanıt düzeyi A). ${ }^{[9]}$

\section{Kaynaklar}

1. Garg R, Yusuf S. Overview of randomized trials of angiotensin-converting enzyme inhibitors on mortality and morbidity in patients with heart failure. Collaborative Group on ACE Inhibitor Trials. JAMA 1995;273:1450-6.

2. Yancy CW, Januzzi JL Jr, Allen LA, Butler J, Davis LL, Fonarow GC, et al. 2017 ACC Expert Consensus Decision Pathway for Optimization of Heart Failure Treatment: Answers to 10 Pivotal Issues About Heart Failure With Reduced Ejection Fraction: A Report of the 
American College of Cardiology Task Force on Expert Consensus Decision Pathways. J Am Coll Cardiol 2018;71:201-30.

3. Ponikowski P, Voors AA, Anker SD, Bueno H, Cleland JG, Coats AJ, et al. 2016 ESC Guidelines for the diagnosis and treatment of acute and chronic heart failure. Kardiol Pol 2016;74(10):1037-147.

4. McMurray JJ, Packer M, Desai AS, Gong J, Lefkowitz MP, Rizkala $\mathrm{AR}$, et al. Angiotensin-neprilysin inhibition versus enalapril in heart failure. N Engl J Med 2014;371:993-1004.

5. Desai AS, McMurray JJ, Packer M, Swedberg K, Rouleau JL, Chen F, et al. Effect of the angiotensin-receptor-neprilysin inhibitor LCZ696 compared with enalapril on mode of death in heart failure patients. Eur Heart J 2015;36:1990-7.

6. Sarrias A, Bayes-Genis A. Is Sacubitril/Valsartan (Also) an Antiarrhythmic Drug? Circulation 2018;138:551-3.

7. de Diego C, González-Torres L, Núñez JM, Centurión Inda R, Mar-
tin-Langerwerf DA, Sangio AD, et al. Effects of angiotensin-neprilysin inhibition compared to angiotensin inhibition on ventricular arrhythmias in reduced ejection fraction patients under continuous remote monitoring of implantable defibrillator devices. Heart Rhythm 2018;15:395-402.

8. Shen L, Jhund PS, Petrie MC, Claggett BL, Barlera S, Cleland JGF, et al. Declining Risk of Sudden Death in Heart Failure. N Engl J Med 2017;377:41-51.

9. Ponikowski P, Voors AA, Anker SD, Bueno H, Cleland JGF, Coats AJS, et al. 2016 ESC Guidelines for the diagnosis and treatment of acute and chronic heart failure: The Task Force for the diagnosis and treatment of acute and chronic heart failure of the European Society of Cardiology (ESC)Developed with the special contribution of the Heart Failure Association (HFA) of the ESC. Eur Heart J 2016;37:2129-200. 